NGUYỄN THỊ MỸ, Linh

DOI: 10.15170/DIKE.2019.03.01.06

PhD student, PTE ÁJK

Lecturer, Can Tho University Vietnam

\title{
The Impact of the French Colonial Law on the Development of Matrimonial Property Law in Vietnam
}

\begin{abstract}
This article analyses the matrimonial property law in Vietnam during the French colonial period. From 1858 to 1954, France invaded Vietnam and applied similar regulations form their homeland to Vietnam. Vietnam has witnessed the term of the matrimonial property law form now onwards. Analysing and understanding the development of the matrimonial property law during French conquest is truly worth researching for Vietnam legal history. This research would be a great idea if it is compared between eastern family regulations and western family ones which were issued during French colonial time. Indeed, the best way to contribute for the improvement of matrimonial property law is to certainly understand its development process.
\end{abstract}

Keywords: matrimonial property law, Vietnam, France, European impact

\section{The influence of historical background on Vietnamese law during French conquest time}

Vietnam is a country in Southeast Asia and influenced by invasions from imperial countries like China (178 BC-9391), France (1858-1954) and the United States (1954-1975). The empire countries have applied regulations and administrative models from their own countries to support the colonial system. Therefore, Vietnamese law during these historical periods was affected by the laws of China and the Western states invading Vietnam.

In 1858, the French empire initially invade Vietnam, which was ruled under the Nguyen Dynasty. The invasion took place step by step throughout major provinces and cities of Vietnam. In 1858, France firstly invaded Da Nang province, ${ }^{2}$ then conquest to provinces in Southern Vietnam. Under the increasing pressure of French colonialism, the Nguyen Dynasty, which governed the territory of Vietnam since 1802 until 1945), accepted the signing of the Treaty of Saigon in 1962. Accordingly, the South of Vietnam became a territory of France and set under full

\footnotetext{
${ }^{1}$ From 179 BC to 939, Vietnam was invaded and colonized by China. Vietnam had gained independence since 939. However, Vietnam always had to deal with invasions from China from 939 to 1858. At this stage, Vietnam was an independent country but was politically influenced by Chinese dynasties. The Vietnamese political system was still under the management and leadership of Vietnamese kings. However, the kings of Vietnam were dominated by China's mighty neighbor. Chinese dynasties, when they came to the throne, tried to rule and colonize Vietnam. Every year, Vietnam must donate valuable assets to the Chinese Dynasties. The management and administration of the Vietnamese Kings were dominated and controlled by China. See VŨ VĂN, Dân luật khái luận 185.

${ }^{2} \mathrm{Da}$ Nang is the largest developing province in Central Vietnam today.
} 
control of the French government. The feudal government of the Nguyen Dynasty only ruled the North and Central regions afterwards. ${ }^{3}$

Through the Treaty of Saigon, France established a government system in the Southern Vietnam (also known as Cochinchine). To ensure loyalty and unification, management and rule in the South were all assigned to French naval officers. Vietnamese people only participate in the management system in the positions of maids and assistants. The management system was ruled by the French, so they needed to build legislation and execution in South Vietnam like French territory. France developed legal regulations for the unified and stable management on the Southern territory. Therefore, the Civil Code in the South was issued in 1883 and written completely in French.

In 1883, France in turn increased the expansion of invasion to the North and Central of Vietnam. Due to the weakness of the Nguyen Dynasty, France forced King Nguyen to hand over the North and the Central to France for protection. ${ }^{4}$ The protection meant that the North and Central regions were not only subject to the management of the Nguyen Dynasty but also under the control of the French colonialists. In the North, the Nguyen Dynasty almost no longer managed the government system, but the French held the main management position. In the Central region, the Nguyen dynasty was placed in Hue, ${ }^{5}$ so its control was still recognized in this place. Therefore, France maintained parallel management with the Nguyen Dynasty in the Central region.

The striking feature is that the North and Central regions were only put under French protection, the Nguyen Dynasty was still involved in state management. Unlikely, the South of Vietnam, which was considered a French territory, was built a new legal system by France. On the contrary, the Northern and Central regions were managed by both the French and the Nguyen Dynasty, so the legal systems were different. At first, France still applied the documents issued by the Nguyen Dynasty earlier to ensure the stability and citizen's consensus. Specifically, Gia Long Code was currently being applied to resolve criminal and civil disputes in the North and Central regions. Gia Long Code was issued by the Nguyen Dynasty in 1812 and published into a book in 1815. ${ }^{6}$ The Gia Long Code had 398 articles $^{7}$ and was known as a penal code. ${ }^{8}$ However, Gia Long Code stipulated not only criminal articles but also civil aspects (66 Articles).

In the North, the application of Gia Long Code was maintained until 1931. From 1931, France enacted the Northern Civil Code and abolished the validity of the Gia Long Code. This civil law was issued bilingual in both French (known as Code Civil à'usage des jurisdictions indigènes du Tokin) and Vietnamese. It had four volumes and 1455 articles.?

\footnotetext{
${ }^{3}$ TAYLOR, A history of the Vietnamese 445.

${ }^{4}$ TAYLOR, A history of the Vietnamese 446.

${ }^{5}$ Hue is a city in Central Vietnam and used to be the feudal capital of Vietnam under the Nguyen Dynasty (1802-1945).

${ }^{6}$ VŨ VĂN Mẫu, Dân luật khái luận 236.

7 VŨ VĂN Mẫu, Dân luật khái luận 258.

${ }^{8}$ Gia Long Code was newly issued in the Decree on July 3, 1933 by the King Nguyen (Vietnam) and the GovernorGeneral (France) and applied in the Central Region. Gia Long Code's new version had all 429 articles. In the introductory clause, the Code was modified only a few things to meet the demand of Vietnamese society and traditional customs. See Bui HuY - BERT, Code Penal de l' Annam 5.

${ }_{9}$ The Northern Civil Code was issued in the Decree dated on March 30, 1931 by the French Ambassador to the north and took effect from July 1, 1931.
} 
In Central Vietnam, the application of Gia Long Code was adhered until 1936. From 1936, France promulgated the Central Civil Code and abolished the validity of Gia Long Code. It was iussed bilingual in both French (known as Code Civil à'usage des jurisdictions indigènes de L'Annam) and Vietnamese (known as Hoang Viet Trung Ky Law) which ensured to apply conveniently to both the French government and the Nguyen Dynasty. The Central Civil Code had five volumes ${ }^{10}$ and 1709 articles.

From 1883 to 1936, Vietnam had existed three separate Civil Codes in the North, Central and South regions. Why did they have three Civil Codes on the same territory? Why did not French issue a unified Civil Code applying to all regions in Vietnam? It is necessary to consider the political context in Vietnam in the past. In 1883, the South was considered a French territory, so they managed and built the South in their own demand. In contrast, the North and Central regions were still under the management of the Nguyen Dynasty, although they were under French protection at the same time. Why did not France enact a civil code that applied generally to the North and Central regions? The reason is because the influence of France in the North and Central region was different. The Nguyen Dynasty was still highly influent in the Central region, because its government system was placed in this area. France's management dominated in the North more than that in the Central, because the power of the Nguyen Dynasty was still concentrated in the latter. In addition, the French invasion policy was to divide the Vietnamese territory into separate parts to rule and undermine the independent revolts of Vietnamese. Therefore, the alienated territory into three regions with three different legal systems was France's main demand.

However, having three civil laws in three regions on the same territory seemed to be a France temporary measure. In fact, the contents of the three Civil Codes were different and caused conflicts of law in practice. Specifically, the marital age in the North was 18-year-old for men and 16-year-old for women (Article 73). In contrast, 16 and 14-year-old were the age of marriage in the south for men and women respectively. If the husband who came from the North got married in the South, he must satisfy the condition of being 18 -year-old under the former law. ${ }^{11}$ Hence, the lawmakers themselves also want to have a unified law for the whole territory. However, the construction of a civil law that applied to the whole territory of Vietnam seems to have been beyond the capabilities of France after the 1930s and 1940s inspiring the success of communism in China. Since 1945 the territory of Vietnam was divided into the North and the South, because the uprising of politician Ho Chi Minh resulted in the independence of the North. Since then, the Northern Vietnam has been under the leadership of the Communist Party and developed in a socialist orientation. Ho Chi Minh, a communist leader, called for the implement equality between men and women. "Hence, expectation grew among women that independence from colonial oppression and the beginning of communist governance would bring about a new and better role for women in Vietnamese society". "On the contrary, France only had influence on South Vietnam. By 1954, France withdrew its troops from

\footnotetext{
10 The first book was issued under Decree No. 51 of July 13, 1936. The second book was issued under Decree No. 95 of January 8, 1938. The third, fourth and fifth volume were issued under the Decree 59 September 28, 1939.

${ }^{11}$ VŨ VĂN, Dân luật khái luận 266.

12 WALSH, The law of the family in Vietnam 69. See also Pothier's paper about the propagandist representation of Vietnamese women.
} 
the territory of Vietnam. From 1954 to 1975, the US, which was an ally of France, replaced France to rule the Southern Vietnam under the President Republic system.

In the field of marriage and family, the application of legal regulations focused mainly on documents such as Gia Long Code (1812), Southern Civil Code (1883), Northern Civil Code (1931) and Central Civil Code (1936). At the beginning of the invasion, France temporarily applied the Nguyen Dynasty's law (mainly Gia Long Code) and indigenous Vietnamese customs. Since 1883, France had gradually changed the traditional lifestyle by Europeanization trends. Typically, France copied almost all the provisions in the First Book of French Civil Code to Vietnam to build the Civil Code in the South. However, the Southern Civil Code only referred the general provisions in the French Civil Code, so many important contents had not been mentioned. Therefore, the Southern Civil Code had not yet acknowledged the existence of the matrimonial community property.

In contrast, France colonists stipulated in detail about the matrimonial community property in both the Northern and Central Civil Codes: "The Northern Civil Code and the Central Civil Code were referred several contents of the French Civil Code". ${ }^{13}$

In short, the historical context of Vietnam during French conquest greatly affected the Vietnamese legal system and the matrimonial property law. Legislation on property was interplay between feudal regulations (Gia Long Code) and Western-style ones. Therefore, the French influence on the legal system of marital property in Vietnam is clearly demonstrated by comparing these Civil Codes in section 2.

\section{The marital property regulations in Vietnam between 1858 and 1954}

\subsection{Regulations on matrimonial property under Gia Long Law 1812}

The Gia Long Code (commonly known as the Hoang Viet Luat Le) was a written law of the Nguyen Dynasty, the last monarchy in Vietnam. This code was composed in the 1811s and issued in 1812 which was initially made from wooden. ${ }^{14}$ In 2009, UNESCO recognized the Nguyen Dynasty's wooden books as the first world heritage document of Vietnam ${ }^{15}$ (see Figure 1). In the late 19th and early 20th centuries, Vietnamese feudal dynasties came into mass publishing by using these wooden stamps. Gia Long Code was a combination between Chinese characters and Nom characters. ${ }^{16}$ It is said that Gia Long Code has many similarities with China's Qing Law. ${ }^{17}$ Regrettably, the Gia Long Code, which copied almost the original text of China's Qing Law, did not reflect the Vietnamese tradition and customs. ${ }^{18}$ Gia Long Code had 22 volumes and 398 articles. The issue of civil status and marriage was adjusted from volume 6th to 8th and had all 66

\footnotetext{
13 VŨ VĂN, Dân luật khái luận 245-247.

${ }^{14}$ NGUYẼ̃̂N QUYẾT, Tìm hiểu Luật Gia Long 9.

15 The Nguyen Dynasty's wooden books are currently stored at the State Bureau of Archives belonged to the Ministry of Home Affairs of Vietnam.

16 Nom characters was used to official Vietnamese language between 939 and 1858. This had totally similarities in comparison with Chinese. When France invaded Vietnam, it was replaced by Vietnamese Roman alphabet which has been the official language until now.

${ }^{17}$ NGUYẼ̃N THI THU, Về mối quan hệ giữa Hoàng Việt luật lệ và Đại Thanh luật lệ 69-80.

${ }^{18}$ HÀ NHƯ, Chế độ hôn sản pháp định trong luật Việt Nam 35.
} 
articles. This was essentially a penal code, so its marriage provisions only set penalties. In the conjugal relationship, the Code only mentions the penalty when the husband and wife violate the principles of moral standard such as the crime of murder to the wife (Article 332), the crime of violence against the husband (Article 281), the crime of violence against the wife (Article 284). Neither the Gia Long Law nor the Chinese's Qing Law stipulated a marital property law because marriage only leaded a woman to merge into her husband's family community.

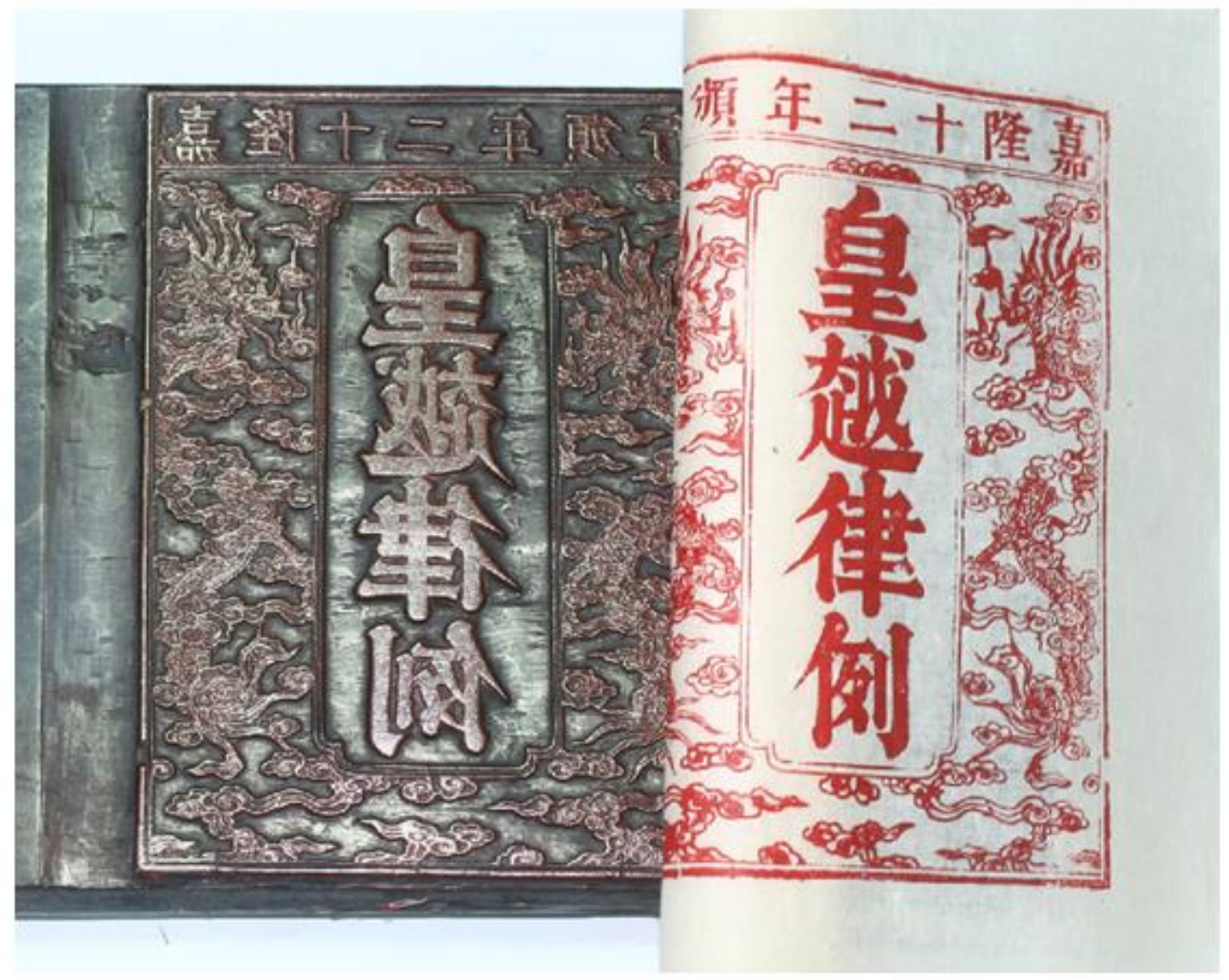

Figure 1: The wooden Gia Long Code

\subsubsection{Property rights of women during marriage under Gia Long Code}

Due to the absence of regulatory principles on matrimonial property law within Gia Long Code, the King issued Directives ${ }^{19}$ and applied the fine customs resolving family disputes. According to the provisions of Articles 37 and 83 of Gia Long Code, if the father deceased, the child would inherit his heritage. Neither of these terms illustrates clearly whether a daughter can inherit her

\footnotetext{
${ }^{19} \mathrm{Ha}$ Nhu Vinh in the book Legislative Marriage mode mentions King and Directive No. 1. However, these Directives
} are hardly mentioned the time of issuance in very details. 
father's legacy or not. The fact that feudal society considered women to be incompetent, so that the daughter's right to inherit seemed impossible. In fact, feudal society of the Nguyen Dynasty valued the dominated position of the father and the eldest son in the family (see Articles 108 and 76). Therefore, it seems reasonable that only a son was entitled to his father's legacy. If the legacy did not have a son inherited, it would be impossible that a daughter was entitled to inheritance. According to the hierarchical principle among family members, it would be much more reasonable that the heritage was put under the control of the grandparents when no son enjoyed his father's legacy. This assumption was proved by Article 2 which stipulated that children and grandchildren must be obliged to respect grandparents and parents (Article 2). Therefore, "it is unlikely that a daughter has her separate property through her father's inheritance". ${ }^{20}$ Moreover, whether it was possible for a woman to have her separate property thanks to her dowry. ${ }^{21}$ Apparently, there were no documents to illustrate this case, because the woman in Nguyen Dynasty was powerless. Therefore, it clearly limited to recognize private possession of women.

Supposedly, even if there was a separate property before marriage, this also merged into the husband's property during marriage period. This was considered an asset consolidation, so there was no private and common property. All assets including movable and immovable ones were under the management and ownership of the husband. According to the King's Directive No. 2 Guiding Article 69 of the Gia Long Code, transactions (such as real estate purchase or donation) must be made in writing. The establishment of written transactions guaranteed ownership and recourse rights of new owners (Articles 87 and 89).

It can be said that the society of Gia Long's king highly praised the absolute role of husband and father in the family. Article 96 of Gia Long Code showed that the husband could be polygamy, but only for men, and had a hierarchy among wives. The first wife had a higher position than the second wife, who was considered a member of the whole family. These wives must respect and obey their husband.

\subsubsection{Wife's property rights upon divorce under Gia Long Code}

The husband was entitled to divorce the wife when the wife commits faults such as adultery, murder the husband or improper behavior toward the husband's parents (Article 103). Specifically, divorcing by an adulterous reason, the wife must not bring any property and be convicted of exile (Article 332). If the divorce was not the wife's fault or the consensual divorce, the law did not mention the consequences of the property ${ }^{22}$. In fact, if the two parties divorce without going through the competent authorities, the husband did not share property with the wife. "If the divorce was settled by a competent authority, the wife shall require the busband to support and compensate". 23 According to historical documents, if the divorce was due to childless reason, the wife was considered non faulty. Hence, she could bring her own belongings to the family such as clothes and personal attire.

\footnotetext{
${ }^{20}$ HÀ NHƯ, Chế độ hôn sản pháp định trong luật Việt Nam 61.

${ }^{21}$ HÀ NHƯ, Chế độ hôn sản pháp định trong luật Việt Nam 189.

22 VŨ VĂN, Cổ luật và Tư Pháp sử 103.

${ }^{23}$ VŨ VĂN, Cổ luật Việt Nam và Tư pháp sử 107.
} 
It is said that that the wife could take personal jewelry because it had little value and only the land was considerably valuable.

However, some obligations were imposed on husbands in marriage. Specifically, Article 284 stipulated that husbands must not commit acts of violence against their wives. The wife was entitled to divorce, if the husband who acted threatens. However, divorce was only possessed when the husband agrees.

\subsubsection{Property rights of the widow under Gia Long Code}

Article 37 of Gia Long's Law showed that a son was entitled to inherit his father's legacy. If the father had much more sons, the legacy would be belonged to the eldest son. Article 83 stipulated that children and grandchildren must not arbitrarily divide the family's assets. Family assets were a unified family and called the family community property. Therefore, the custom showed that the eldest son would inherit the estate when the father decease. "If the mother had not remarried yet, she would be entitled to usufruct her husband's property". ${ }^{24}$ However, the wife would be deprived this right, if she remarried or acted as immoral as disrespectful to parents-in-law.

The wife was entitled to not remarry when the husband demised, the person who forced the wife to remarry was considered guilty ${ }^{25}$ (Article 98$)$. This regulation has two meanings: i) encouraging the widow dignity; ii) limiting parents-in-law and the eldest son depriving the widow's usufruct.

In addition, Article 76 and Directive No. 2 prescribed that the widow was still allowed to remarry after mourning three years, but she shall refund husband's property which was assigned to the husband's family.

Nevertheless, Gia Long Code did not prescribe the existence of a wife's legacy when she deceased. It is said that the wife was not acknowledged to have private property, so there was no wife's inheritance apparently.

In short, the provisions in Gia Long Code entered responsibilities and duties between husband and wife, but there were absolutely lack of property regulations. Indeed, feudal society considered the family to be a unified association under the leadership of the husband. Therefore, property issues were managed and controlled by the husband.

\subsection{Provisions on matrimonial property law under the Southern Civil Code}

Based on the treaty of 1862 and 1874, the Nguyen Dynasty accepted the South and three major cities of Hai Phong, Da Nang and Hanoi to become French colonies. France had built a separate legal system on these colonies. The Directive dated May 25, 1881, was issued by France government which stipulated that disputed in the south would be arbitrated by French judges. Therefore, building legitimate in this region became necessary. The original rules of law were enacted in three

\footnotetext{
24 POMPCI, Le Droit familial et matrimonial au Viet Nam 233.

${ }^{25}$ Gia Long Code provided many forms of punishment: death penalty, imprisonment, border hard labor, fine, whip punishment.
} 
categories: volume 1st: nationality; volume 2 nd: Civil status; volume 3 rd: residence. Volume 1 st and 3rd were built the same as volume 1st in the French Civil Code. ${ }^{26}$

Volume 2nd dated October 3, 1883, which was issued by the French President. This book had seven chapters including from chapter IV to chapter X which stipulated on marriage and family law. These chapters were issued on March 26, 1984. This second volume was commonly known as the simplified Civil Code of the South. Chapter IV-X in turn regulated the issues of missing, marriage, divorce, parent-child relationship, foster relationship, personal rights, juvenile and guardian.

The Civil Code 1883 was applied in the South and three major cities ${ }^{27}$ of Hanoi, Hai Phong, ${ }^{28}$ and Da Nang. This civil law was quite sketchy, especially not regulated the aspects of marriage and inheritance. Legislators argued that there was a big difference in marriage and family laws between Vietnamese and French at that time, because Vietnamese feudal law emphasized the patriarchal value of a man. Therefore, they could not copy the provisions of French Civil Code 1804 on matrimonial property law into the Southern Civil Code 1883. This explains why the latter was lack of regulations on marital property. In fact, the judges dealing with matrimonial property disputes must comply with the provisions of Gia Long Code and the traditional custom of Vietnamese. "In addition, if the above two laws did not anticipate all property disputes between husband and wife in South Vietnam, the Judge shall apply case laws to settlement". ${ }^{29}$ Case laws were derived from domestic and French legal cases (mainly civil obligations) that were all applied in Vietnam. In fact, French judges initially applied French case laws ${ }^{30}$ into settlement between Vietnamese litigates. However, several legal French cases could not be adhered in Vietnam due to differences between legal regulations. Specifically, the law on marriage between France and the South were completely different, so it was impossible to manipulate the former's family case laws into the latter. From 1895 onwards, case laws in the South was formed and collected into monographs as "Journal judiciaire de La Conchincbine et du Cambodge". ${ }^{31}$

\subsubsection{Property rights of the wife during the marriage period under the Southern Civil Code}

In general, the marriage and family law in the South did not acknowledge the marital community property. Accordingly, the wife was completely incompetent when she got marriage. The husband, however, was entitled to polygamy due to the influence of Confucianism ${ }^{32}$ through the period of

\footnotetext{
${ }^{26}$ VŨ VĂN, Dân luật khái luận 282.

${ }_{27}$ Three major cities, which are not in the South but still under French control, are large cities and hold important sea trade positions.

${ }^{28}$ Hai Phong is a port city in the Northeast of Vietnam.

${ }^{29}$ VŨ QUỐC, Pháp chế sử 27.

30 The French's case law was later translated into Vietnamese by two Vietnamese judges (Important case law). See TRẦN THÚC - NGUYỄN VĂN, Những án lệ quan trọng.

${ }^{31}$ République Française published the Journal judiciaire de La Conchinchine et du Cambodge which were the collection of civil and criminal case laws in Vietnam and Cambodia during the year 1895.

32 Confucianism is one of the major schools of Chinese philosophy in ancient times that were philosophical, moral, and institutional ideologies that had a basis in China from the West Chu period, to the end of the Spring and Autumn period. (TKXI-TKV BC). After that, Confucius (551-479TCN) and his disciples, Manh Tu (372-289 BC) and Tuan $\mathrm{Tu}$ (313-238 BC), systematized and stabilized the two classic sets including the Four Letters and Pentateuch. These
} 
Chinese invasion and previous domination. The husband was the owner and the property manager of the whole family. "Therefore, the wife had no separate property and was not involved in the administration of the family's production". ${ }^{33}$ In addition, the husband was the legal representative for the wife and the lawsuit must be represented by the husband. The wife could only participate in the legal proceedings when her husband agreed (chapter X relating to guardian).

\subsubsection{The wife's property rights regarding divorce under the Southern Civil Code}

The husband or the two parties were enabled to file for divorce. The husband shall file for divorce due to the wife's faults, but the wife's divorce right was limited (Article 108). ${ }^{34}$ In addition, case laws also seemed to acknowledge the wife's right to receive certain personal properties, if there was no fault. Specifically, the wife was entitled to receive property which was personal belonging (Manh Nhu Thien vs Thi Diep, November 22, 1898) or donated property separately (Nguyen Hun Nga vs Nguyen Thi Sang, October 14, 1898). The wife was also entitled to ask the husband to support depending on the actual ability of the husband. ${ }^{35}$ However, according to chapter VI, the wife was not able to assign any property and support, if she had fault causing for divorce. ${ }^{36}$

\subsubsection{Property rights of the widow under the Southern Civil Code}

If the husband demised, the widow privileged to usufruct and administer without inheritance the husband's legacy. However, if the widow remarried, the husband's property would be returned to the eldest son to inheritance. In the case of a polygamous husband, the wife's eldest son was the heir. For example, the first-instance verdict, which was at My Tho Court ${ }^{37}$ dated December 4, 1894, between Doan Thi Y and her son Nguyen Van Sam, settled that the eldest son would be a father's heir. Mrs. Doan Thi Y was Nguyen Van Phat's wife. After Mr. Phat deceased, Mrs. Y remarried to Mr. Tran Van Loi. This trail defined Mrs. Y having an obligation to delivery all her husband's legacy to her eldest son, Nguyen Van Sam. However, the appellate judgment dated March 14, 1895 of the Saigon Supreme Court modified that Nguyen Van Sam who was Mr. Phat's heir had an obligation to subsidize Mrs. $Y$ for $4 \$ /$ month. ${ }^{38}$ Thus, the widow must be responsible for handing over the husband's property to the eldest son and was entitled to claim benefits from her husband's legacy.

volumes were then compiled by the Confucian students who composed the teachings of Confucius. Confucianism absolutizes the King's right in society and the rights of the father in the family. From the point of view of the patriarchal lineage and from the attitude of women's neglect, Confucian philosophy puts the brotherhood higher than the husband and wife relationship. Women are the ones who suffer the most disadvantages due to harsh regime, injustice and inequality in society as well as in families. According to the morality of virtue, a man can have many wives, but women cannot have many husbands. See VO THI CAM, Sự du nhập và ảnh hưởng của Nho giáo đến giá trị truyền thống văn hóa Việt Nam. http://vanhoanghean.com.vn/chuyen-muc-goc-nhin-van-hoa/nhung-goc-nhin-van-hoa/su-du-nhapva-anh-huong-cua-nho-giao-den-gia-tri-truyen-thong-van-hoa-viet-nam.

${ }^{33}$ HÀ NHƯ, Chế độ hôn sản pháp định trong luật Việt Nam.42.

34 VŨ VĂN, Dân luật lược khảo 550-560.

35 PHAN VĂN, Phụ nữ Việt Nam trước pháp luật 51.

36 VŨ VĂN, Dân luật lược khảo 600.

${ }^{37} \mathrm{My}$ Tho is a district of Tien Giang province - Southeastern Vietnam.

${ }^{38}$ République Française, Journal judiciaire de La Conchinchine et du Cambodge 237. 
In general, case laws recognized that the wife had no separate property and the husband was the head of the family. However, there were few judgments that go against the principles mentioned as a trail dated December 30, 1889, recorded by the Civil Court in Long Xuyen. ${ }^{39}$ However, this verdict was finally canceled by the Saigon Supreme Court ${ }^{40}$ dated April 30, 1908, due to the inconsistency with the contents of the Southern Civil Code $1883 .{ }^{41}$

It seems that the judges were aware of the limitations of the Southern Civil Code regarding to the rights of the wife. Meanwhile, the French society allowed the wife to have separate property. The Decree dated December 5, 1935, was issued by the Governor-General of Indochina forming a Committee for drafting the new Civil Code. A Bill was established and referenced the progress ideas of the French Civil Code on marital property law. However, this Bill was not adopted during the French colonist, because France was weakened by successive defeats of Vietnamese. ${ }^{42}$ From 1954 to 1975, the US was an ally of France and replaced it to colonize this area. In 1959, under American rule, this region had a Family Law ${ }^{43}$ issued by the President Republican. "Many of the contents of the Bill of the Southern Civil Code were consulted to build this Family Law". ${ }^{45}$

\subsection{Provisions on matrimonial property under the Northern Civil Code 1931}

The Northern Civil Code was issued on March 30, 1931, and promulgated since July 1, 1931. Gia Long Code had been terminated in the North from this point onwards. "The law on marriage and family stipulated in the first volume (focusing from Article 68 to Article 461)". "It referred to almost the French Civil Code. It can be concluded that the concept of community property began to formation since then. Moreover, the law on matrimonial property allowed couples to choose an agreed property or a statutory one. In addition, the separate property was admitted to the wife (Article 113).

Unlike the South, the Northern Civil Code was built on the legal principle of writing, so the judges mainly based regulations prescribing within this. The application of the case laws was not used in trial since the Northern Civil Code 1931 was issued. It prescribed rather almost detailed civil laws than the Gia Long Code.

\footnotetext{
${ }^{39}$ Long Xuyen is a city at An Giang province in the Southwest region of Vietnam today.

40 Saigon City was the largest city in South Vietnam at that time. After 1975, the South was completely liberated and unified, the city was renamed as Ho Chi Minh City so far. Hồ Chí Minh (1898-1969) is the name of the leader of Vietnam who made great contributions to the resistance against the French and the Americans. See Vietnam News Agency, Chính phủ Việt Nam năm 1945-1998,

http://chinhphu.vn/portal/page/portal/chinhphu/NuocCHXHCNVietNam/ThongTinTongHop/ChutichHoChi Minh.

${ }^{41}$ HÀ NHƯ, Chế độ hôn sản pháp định trong luật Việt Nam 87.

42 France was defeated by Viet Minh army in the Battle of Điện Biên Phủ in 1954 in Vietnam and retreated from Indochina. See https://edition.cnn.com/2013/07/09/world/world-war-ii-fast-facts/index.html.

${ }^{43}$ Family Law No. 1/59 dated January 1, 1959 enacted by The President (Ngô Đình Diệm) of Democratic Republic in the South of Vietnam.

${ }^{44}$ From 1954-1975, Vietnam was divided two part as follow the North and the South. The North was independent since 1945 and follows the socialism. Meanwhile, the South of Vietnam was under the control of the USA and followed the Presedent Republic.

${ }^{45}$ HÀ NHƯ, Chế độ hôn sản pháp định trong luật Việt Nam 103.

46 PHAN ĐĂNG - TRƯƠNG THỊ Hòa, Các chế độ hôn nhân và gia đình Việt Nam xưa và nay 40.
} 


\subsubsection{Wife's property rights during the marriage period under the Northern Civil Code}

According to Article 106 of the Northern Civil Code and if the husband and wife did not establish an agreement (which can be interpreted as a type of property law as agreed in contemporary law), the community property which was the statutory would be applied automatically. The concept of a community property original was presented Article 1041 of French Civil Code.

If the husband and wife did not have an agreement on property, then the community property was applied. All assets during marriage time belonged to the community property including the estate or real estate that the couple was donated and inherited (Article 106). This showed that separate property could be formed under the agreed one.

\subsubsection{The property rights of the wife after divorcing under the Northern Civil Code}

The rule of divorce laws had changed in a positive way for the wife. They could file for divorce as non-mutual or mutual consent divorce. In contrast, Gia Long Code only allowed the husband to divorce his wives. There were differences in property interests between the first wife and second wife after divorcing. The second wife must not share the community property. The entire community property was only recognized between the husband and the first wife (Article 119). If the second wife did not have the same domicile with her husband and established her property separately, she was entitled to retain those assets (Article 148).

If the divorce did not have the wife's fault and any other agreements, the first wife was entitled to divide the community property (Article 112 and 147). "In addition, according to Article 112 of the Northern Civil Code, it was possible for the husband and wife to receive personal property supporting personal needs such as clothes, books and personal works tools". ${ }^{47}$ In particular, the husband had responsibility to support the wife as a reward for her dedication during marriage period.

On the contrary, if the divorce due to the wife's fault, the wife was forced to return the valuable jewelry which was donated by the husband's family on their wedding day. However, the community property was still divided for each party in this case. This showed that even if the wife was at fault, the community property was still divided in two. This was a progressive regulation recognizing the different aspects between property ownership and divorce.

\subsubsection{Property rights of the widow under the Northern Civil Code}

The rights of the widow did not seem to be guaranteed. Article 113 stipulated that the widow was entitled to administer and usufruct community property, if she did not re-wed. If the eldest son was mature, he and the mother could agree to divide the legacy.

If the widow remarried, she was entitled to take her personal belongings. The husband's property including community one was handed over to his heirs as follow parents-in-law and the mature son. The second wife did not receive these privileges as the first wife. The second wife did not enjoy her husband's heritage as the first wife. However, the second wife had the right to

\footnotetext{
47 VŨ VĂN, Dân luật lược khảo 601.
} 
usufruct when the legacy was not divided, if she did not remarry and obey the first wife. (Articles 340-365). On the other hand, if the wife demised, the husband was entitled to possess the entire community property and separate belongings of the wife (Article 368).

In general, the provisions of the Northern Civil Code had made significant progress compared to Gia Long Code. It acknowledged the wife's right to separate property and allowed the agreement on property between the couple. When the couple divorced, the wife was entitled to request support and divided community property. The wife was entitled to get back her separate property when the couple divorced. However, it is undeniable that there were still many drawbacks. Equity in property ownership had not been recognized. For example, the right to manage community property was remained by the husband. When the wife deceased, the husband continued to own the community property and his wife's separate property. The succession of the wife's estate was not considered.

\subsection{Provisions on matrimonial property under the Central Civil Code 1936}

The Northern Code of Law was used as a template for the Central Civil Code. It had 5 volumes and was issued in the period from 1936 to 1939. The marital property regulations were issued in 1936 and focused mainly on Articles 104-114. "This law had several similarities in comparison with to the Central Civil Code and only a few changes". 48 The fundamental different was the layout. Specifically, chapters 11 and 12 relating to inheritance, which were prescribed on the first volume of the Northern Civil Code, were on the second volume of the Central Civil Code. The latter exceed the former by 245 articles that referred to contract's regulations. ${ }^{49}$ Therefore, the law on matrimonial property had almost no difference between the two laws.

\subsubsection{The property rights of the wife during the marriage period under the Central Civil Code}

Like feudal regulations, Article 79 recognized the husband to polygamy. The second wife could be lived with an extended family including the first wife. In this case, the second wife did not have her own property and depended on both the first wife and the husband's patriarchal rights (Article 114 of the Central Civil Code).

If the husband accepted that the second wife could live separately from the first wife and her husband, she shall establish a separate property. "If the husband owed a debt, the second wife had no obligation to pay the debt on behalf of her husband. When the husband deceased, she still retained her own assets (Article 223 of the Central Civil Code). This part of property was not merged into the whole community property managed by the first wife, when the husband demised". 50

However, the couples only formed community property when they created a separate family and did not live together with their parents. According to Article 206 of the Central Civil

\footnotetext{
48 PHAN ĐĂNG - TRƯƠNG THI, Các chế độ hôn nhân và gia đình Việt Nam xưa và nay 40.

${ }^{49}$ VŨ VĂN, Dân luật khái luận 292.

50 VŨ VĂN, Dân luật lược khảo 603.
} 
Code, the matrimonial property only applied when the husband was the head of family and had full authority to represent the members living together in the family. The patriarchal right of a husband was meant to be the head of the family. Therefore, children and grandchildren, even if they got married, were still dependent on the patriarchal rights of their father. If the parents were still alive, children must depend on the father and did not have their separate belongings. If a child who was mature and married, he had the right to leave in term of his father's consent. When the son established his own family, the matrimonial property was formation. Like the Northern Civil Code, the Central Civil Code prescribed that there were two types of marital properties which were the agreed property or the community one. The agreed property model was enabled the couple to agree on the ownership, while the entire community property only recognized the existence of common property. The form of an agreed property would only valid, after it had been expressed in writing and legalized by a competent authority. This agreement could not modify, when the parties had established. When the marriage dissolved, this agreement was automatically terminated. It would be noted in marriage certificates to inform and protect the third person in established transactions with spouses. ${ }^{51}$ This term had similarities in comparison with Article 1393, 1394, 1945 of the Napoleon Code $1804 .^{52}$

\subsubsection{The property rights of the wife regarding divorce under to the Central Civil Code}

According to paragraph 2 of Article 104 of the Central Civil Code, estate and real estate, which were sometimes formation before marriage, or inherited or created during the marriage period, belonged to the community property as a statutory law. The husband and wife would not have their separate ownership. If the couples divorced due to childless, then the whole community property would be paid and divided. The wife was entitled to ask for one thirds of the community property.

If the wife was adultery, she would not receive anything to the community property. This was considered a difference compare to the Northern Civil Code. According to the Northern Civil Code, the wife was still assigned a half of community assets, although she had fault. In addition, the Clause 5, Article 110 of the Central Civil Code stipulated that the husband and wife can request to receive their separate properties for personal needs such as clothes, books and personal works tools.

\subsubsection{Property rights of the widow under the Central Civil Code}

According to Article 58, when a spouse was missing, asset management was allocated to the other partner. Specifically, if the husband was missing, the property was assigned to his wife to manage and usufruct. If there was no wife in advance, the property was appointed to the parent or child (mainly as the eldest son) for management. However, this property was not allowed to be sold by the law to predict the possibility of the missing person returning, but the first wife was entitled to

\footnotetext{
51 PHAN VĂN, Phụ nũ̃ Việt Nam trước pháp luật 58-59.

${ }^{52}$ Decree dated February 10, 1804 and promulgated the $20^{\text {th }}$ of the same month in France.
} 
dispose her separate property (Article 67). If the missing person did not return beyond 20 years, the property was considered a legacy and inherited (Article 65). In addition, there was a difference in the management of the missing husband's assets between the first wife and the second wife. The second wife did not take advantages of the husband's property. If she did not remarry, she could stay in the husband's house and be supported.

In the case of a husband's death, the first wife could manage the community assets (Article 222 of the Central Civil Code). Unless she remarried or was disqualified from the husband's legacy, she was entitled to take back personal possession. The husband's property would be assigned to parents-in-law and children (Article 227 of the Central Civil Code). In contrast, if the wife demised, the husband who had full power to possess the whole community assets including the wife's personal property even if the husband remarried (Paragraph 3 Article 111 of the Central Civil Code).

In general, there was few differences between the Central and Northern Civil Codes on marital property law. The Central Civil Code recognized the formation of the matrimonial property and was entitled parties to agree on property. The role of the wife was increasingly recognized through the wife's separate property and the right to share community asset. However, the Central Civil Code was somewhat more restrictive than the Northern Code relating to the provisions of community possession, when the couples divorced. The wife in the Central region only received one thirds of the common property, if she did not have any fault. On the contrary, she would be deprived anything to common property, if she had a fault. Generally, the copying of Napoleon Code encouraged the Central and Northern Civil Codes have several progressive legal ideas. However, these two laws still valued the role of the husband and the son as the head of the whole family.

\subsection{Vietnam's matrimonial property law in comparison with the French Civil Code 1804}

French Civil Code was enacted on March 21, 1804 and known as the Napoleon Code. ${ }^{53}$ Indeed, the impact of French Civil Code goes beyond its territory including not only in Europe countries (Belgium, the Netherlands, Monaco) but also other parts of the world (Asia, Africa, Quebec, Louisiana). It cannot be denied that it has outstanding features as clear structures and styles and a symbolic point of view. Thus, several parts of this still valid for more than two-hundred years. "Although it has remained in force retaining a majority of its original provisions, it has undergone considerable transformations making its evolution a fascinating focal point for continental lanyers". ${ }^{4}$ Therefore, there are major modifications which have been issued throughout the $19^{\text {th }}$ and $20^{\text {th }}$ centuries. ${ }^{55}$ Over time, the French civil law system was subject to the common law system. Therefore, the French Civil

\footnotetext{
${ }^{53}$ LOBINGIER, Napoleon and his code 117.

54 PARIS-DobOzY, Still Alive: Some Observations about the Two-Hundred Years of Existence of the French Code Civil 91.

${ }^{55}$ For instance, the reestablishment of divorce (1884), the reform of the law of marriage $(1896,1907)$, the inheritance rights of natural children (1896) and the admission of paternity search (1912), the law on the respect of human integrity (1994), the law on the electronic signature (2000) and the law on the reform of successions (2001) have been among these amendments.
} 
Code not only applies narrowly in the prescribed provisions but also recognizes the participation of judges in creating case laws in practice..$^{56}$

Vietnam is considered one of the Asian countries affected by the French Empire's regulations. In fact, the Southern Civil Code 1883, the Northern Civil Code 1931 and the Central Civil code are among typical examples that had several similarities in comparison with the French Civil Code 1804.

\subsubsection{The right of the wife during marriage period under the French Civil Code}

The French matrimonial property law was defined from Articles 1389 to 1421 in Title V of the contract of marriage and the respective rights of marriage persons. This title was issued by a Decree dated February 10, 1804 and promulgated the $20^{\text {th }}$ of the same month in France. Accordingly, the couple had two matrimonial property laws to choose from two so called regimes ${ }^{57}$ : a community property (including movable and immovable properties which were acquired during the marriage - Article 1401) or dowry property. The dowry regulation was understood as the wife's separate property, but she still ensures the marital common obligation. ${ }^{58}$

However, the dowry property only applied when the couple had an agreement before marriage. Thus, the community property law would automatically apply, if the couple had no property agreement. However, setting dowry property law must comply with certain forms. Specifically, according to Articles 1394, 1395 and 1396, the French Civil Code stipulated that "All matrimonial agreement shall be reduced to writing before the marriage by act before notary. They cannot receive any alteration after the celebration of marriage". When the dowry law was established, the wife had ability to full control over her separate property and real estate. ${ }^{59}$ However, the husband properly had the right to use the wife's estate during the marriage. ${ }^{60}$

Regarding statutory property, according to Article 1401, the community property was consited all movable properties (including properties possessed before and during marriage, even though succession or donation if the donor had not expressed himself/herself to the contract) and immovables which acquired during marriage. There was also the excluding community property that was considered as spouse's separate properties. These were established through their agreements such as personal goods or immovables derived from inheritance, donations or having before marriage. ${ }^{61}$

Nevertheless, articles 1421 and 1428 of the French Civil Code stipulated that only the husband had the right to manage the community property even the separate property of the wife. The man still played the most important role in family.

\footnotetext{
${ }^{56}$ PARIS-DobOZY, Still Alive: Some Observations about the Two-Hundred Years of Existence of the French Code Civil 95.

${ }^{57}$ Matrimonial property law regimes were at first described by the so called German Historical Law School, and the word „regimes” were used in the private law science preferably only from the second half of the 19th century. See HERGER, A modern magyar házassági vagyonjog a német jogfejlődés tükrében 5-35.

${ }^{58}$ PINTENS, France and Belgium - Marital Agreement and private autonomy perspective 68.

${ }^{59}$ Article 1536 of French Civil Code 1804.

${ }^{60}$ Article 1533 of French Civil Code 1804.

${ }^{61}$ Article 1432 of French Civil Code 1804.
} 
Thus, this law noted that in case where the husband and wife chose the community property law, they still had the right to possess separate property. Meanwhile, civil laws in the North and in the Central only recognized one type of property within the couple's community property. However, these laws had progressed more than the Southern one by acknowledging the existence of the couple's community property law during the marriage period. In contrast, the Southern Civil Code did not recognize the existence of the community property law and was entitled the husband to possess the entire property of the whole family.

However, it must be admitted that the different aspects of French law during this period was enable Vietnamese law to aware the community property. Indeed, from the historical point of view, Vietnam was greatly influenced by Chinese Confucian during the period Chinese conquest (from 179 BC to 939). Therefore, the husband was considered the head of the family and the holder of all family assets. The wife was virtually unprotected and proletariat. ${ }^{62}$ Therefore, the ideology of the property community law in French law brought a progressive idea to Vietnamese law. Vietnam eventually acknowledged the existence of a community property law in which the wife was a companion to her husband in the possession of community property during the marriage period. However, there was still several obstacles within French Civil Code that the husband was the head of family and had the supreme right to manage the comnunity asset including the wife's property.

\subsubsection{The wife's property right after divorce under the French Civil Code}

According to the community property law, when the couples agreed to divorce, they were entitled to split their community property. ${ }^{63}$ The wife may ask to be supported after a divorce, if she was in need. ${ }^{64}$ Accordingly, "case law dated June 25, 185 recognized that the wife was entitled to ask the husband to support upon divorce (Mrs. Guillemant vs Mr. Hanot)". "The French Court determined that if the husband did not fulfil this obligation, the wife was entitled to ask for Hanot's assets to be distrained to enforce his support obligation. If the wife had established a dowry law, she would be able to take back all her personal possessions including estate and real estate. If the husband causes damage to his wife's property, he must compensate. ${ }^{66}$ The detailed rule of dowry law guaranteed the ownership of the wife's private property upon divorce.

\footnotetext{
62 This was reflected in the content of two major laws that were issued in Vietnam during the period of Chinese conquest. Both Hong Duc Code and Gia Long Code only recognized the husband as the head of the family. The Hong Duc Code (also known as the Penal Code of the Le Dynasty) was compiled several times in the years 1470-1497 under King Le Thanh Tong of the Le dynasty. The Code (also known as the Code) was issued in 1812 Gia Long King under Nguyen Dynasty. See VŨ VĂN, Cổ luật Việt Nam và Tư pháp sử 193-205.

63 Article 305 of French Civil Code 1804.

${ }^{64}$ Article 280 of French Civil Code 1804.

65 TRẦN THÚC - NGUYỄN VĂN (translated), Những án lệ quan trọng 404. This consisted of a collection of important legal cases of the French translated by two Vietnamese judges in order to learn and apply in trials by Vietnam court.

${ }^{66}$ Article 1564, 1565 of French Civil Code 1804.
} 


\subsubsection{The rights of widow under the French Civil Code}

Under the dowry law, when the wife deceased, the legacy belonged to the wife's heirs. The husband and his heirs were entitled to use this property. However, if the husband deceased, the wife was entitled to continue to maintain dowry law along with her husband's heritage to ensure daily life but to implement every year. ${ }^{67}$ According to the community property law, when the wife demised, the husband regained his own property and a part of the community property. His wife's estate will include the wife's private property and a part of community property. Similarly, when the husband demised, the widow was entitled to consolidate her own property and wife's share of community asset. The spouse's legacy would be divided among his/her heirs (Article 1478). The beneficiary of the wife and husband's inheritance was "natural children, ${ }^{68}$ afterwards to the spouse surviving, and if it was not of those, to the state". ${ }^{69}$ Different from feudal law, the widow would receive her husband's legacy, if there was no natural children's inheritance.

In conclusion, the French invasion of Vietnamese territory was a wrongful act and caused much damage to both Vietnamese and French. However, it is hard to deny that Vietnam's culture and legislature adsorbed achievements of French civilization. In marriage and family fields, France replaced the feudal ideology which despised the position of women in the family and upheld the absolute position of the man. There was a huge difference in women's property ownership in Gia Long Code compared to the Northern and Central Civil Codes. Gia Long law prescribed women as incompetent, so they had almost no asset in the family. In marriage, family asset belonged to the husband and would be assigned to the eldest son when the father deceased. The wife could only benefit as she did not remarry. This was the result of copying of the Chinese's Qing Law. In contrast, the acquisition of the contents of Napoleon Code encouraged the Northern Civil Code and the Central Civil Code connecting closer to contemporary legislative civilization. Indeed, these laws recognized the wife achieving in a higher position, even though there was not equal completely between both sexes. In terms of scale, the Southern Civil Code was sketchier than the two mentioned laws. Provisions on matrimonial property law were not mentioned in the Southern Civil Code. The copying of the general provisions of the French Civil Code did not provide the necessary laws to resolve social relations arising in Vietnam. Hence, French judges shall apply Gia Long Code and case law in the South. The judges had realized that the law should recognized and respected the ownership of the women relating to divorce and inheritance aspects. It is possible to say that the law of matrimonial property at this stage is a mix of western and feudal ideas where the rationality in Western law seems to prevail. Nevertheless, the matrimonial property law in Napoleon Code 1804 still had inequal regulations which biased to the husband. The wife was quite not equal as the husband in all aspects. Thus, the matrimonial property regulations in French Civil Code had undergone several amendments afterwards.

\footnotetext{
${ }^{67}$ Article 1570 of French Civil Code 1804.

68 Article 334 of French Civil Code 1804.

${ }^{69}$ Article 734 of French Civil Code 1804.
} 


\section{Bibliography}

Bui Huy Tin - Reu, Paul Bert: Code Penal de l'Annam - Hoang Viet in law. Saigon 1933

HÀ NHƯ Vinh: Chế độ hôn sản pháp định trong luật Việt Nam (The legal marriage regime in Vietnamese law). Saigon, 1967.

HERGER Csabáné: A modern magyar házassági vagyonjog a német jogfejlődés tükrében (Modern Hungarian matrimonial property law in the mirror of the German legal development). Passau 2017

LOBINGIER, Sumner Charles: Napoleon and his code. Harvard Law Review, Volume 32, 1918/2 114-134.

NGUYẼ̃N QUYẾT Thắng: Tìm hiểu Luật Gia Long (Research on Gia Long Law). NXB Văn hóa thông tin, 2002

NGUYẼ̃N THI THU Thủy: Về mối quan hệ giữa Hoàng Việt luật lệ và Đại Thanh luật lệ, Tạp chí Nghiên cứu Trung Quốc số 7(119) 2011, 69-80.

PARIS-DoBOZY, Marie-Luce: Still Alive: Some Observations about the Two-Hundred Years of Existence of the French Code Civil 1804. Irish Journal and European Law, volume 12, 2005

PHAN ĐĂNG Thanh - TRƯƠNG THỊ Hòa: Các chế độ hôn nhân và gia đình Việt Nam xưa và nay (The old and new matrimonial property regimes in Vietnam). Ho Chi Minh city 2012

PHAN VĂN Thiết: Phụ nữ Việt Nam trước pháp luật (Vietnamese women in accordance with the law). Saigon 1955 PINTENS, WALTER: France and Belgium - Marital Agreement and private autonomy perspective. Oxford - Portland 2012

POMPCI, P.: Le Droit familial et matrimonial au Viet Nam (The matrimonial property law in Vietnam). Saigon 1951

PothieR, Christin M.: Propagandist representation of Vietnamese women. 2003

https://www.semanticscholar.org/paper/PROPAGANDIST-REPRESENTATION-OF-VIETNAMESE-

WOMEN\%3A-A-Pothier/a052604e3a88cdfaa7f1c3829571bd37c9a204ec (01.09.2019)

TRẦN THÚC Linh - NGUYẼ̂̃N VĂN Thọ (translated): Nhũng án lệ quan trọng (Important cases). Saigon 1962

TAYLOR, K. W.: A history of the Vietnamese. Cambrigde 2013

VÕ THI CẨM Vân: Sự du nhập và ảnh hưởng của Nho giáo đến giá trị truyền thống văn hóa Việt Nam (Confucian introduction and influence to the value of Vietnamese cultural traditions), http:/ / vanhoanghean.com.vn/chuyen-mucgoc-nhin-van-hoa/nhung-goc-nhin-van-hoa/su-du-nhap-va-anh-huong-cua-nho-giao-den-gia-tri-truyen-thong-vanhoa-viet-nam (February 22, 2019)

VŨ QUỐC Thông: Pháp chế sử (Legal History). Saigon 1968

VŨ VĂN Mẫu: Cổ luật Việt Nam và Tư pháp sử (Vietnamese Law and Judicial History). Saigon 1973

VŨ VĂN Mẫu: Dân luật lược khảo (Civil Law Review). Volume 1: Family. Saigon 1962

WALSH, Thomas J.: The law of the family in Vietnam. California Western International Law Journal: Vol. 42 : No. 1 , Article 4. https://scholarlycommons.law.cwsl.edu/cwilj/vol42/iss1/4 (01.09.2019) 